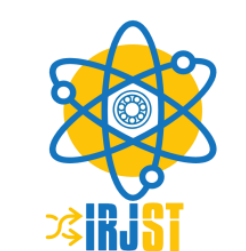

Available online at https://www.irjst.com/

International Research Journal of Science and Technology

ISSN: 2707-3955

DOI: https://doi.org/10.46378/irjst.2020.010404

\title{
Determinants of Entrepreneurial Intentions in University Graduating Students, Ethiopia An Empirical Review of Selected Papers
}

\section{Adissu Ketemaw*}

Department of Management, Bonga University ,Ethiopia.

\begin{tabular}{llll}
\multicolumn{2}{l}{ Paper Status } & & \\
\hline Received & $:$ & Aug & 2020 \\
Accepted & $:$ & Sep & 2020 \\
Published & $:$ & Sep & 2020
\end{tabular}

Key Words

Attitude

Entrepreneurial Intention

Personal Background

Perceived Behavior

Subjective Norm

Copyright (C) 2020: Adissu Ketemaw. This is an open-access distribution, and reproduction in any medium provided Access article distributed under the Creative Commons Attribution License the original work is properly cited License, which permits unrestricted use.

Citation: Adissu Ketemaw. “Determinants of Entrepreneurial Intentions in University Graduating Students, Ethiopia.An Empirical Review of Selected Papers”. International Research Journal of Science and Technology, 1 (4), 292-298, 2020.

\section{Introduction}

Entrepreneurial development is the most important input in the economic development of any country. The objectives of industrial development, balanced regional growth, and generation of employment opportunities are achievable through entrepreneurial development. Entrepreneurs are at the core of industrial development which results in greater employment opportunities to the unemployed youth, increase in per capita income, higher standard of living

\footnotetext{
* Corresponding Author: Adissu Ketemaw

Bonga University Department of management,Ethiopia.

Email: adissuketemaw8@gmail.com
}

and increased revenue to the government in the form of income, sales tax, export duties, import duties etc [1].

Entrepreneurial higher education institutions are designed to empower staff and students to demonstrate enterprise, innovation and creativity in research, teaching and pursuit and use of knowledge across boundaries. They contribute effectively to the enhancement of learning in a societal environment characterized by high levels of uncertainty and complexity and they are dedicated to creating public value via a process of open engagement, mutual learning, discovery and exchange with all stakeholders in society - local, national and international." (Gibb \& Haskins, 2014) cited by [1] 
The youth involvement in the economic struggle is of paramount importance. Developing them to have the spirit and drive towards entrepreneurship would mean preparing them to become successful and useful in the society and in the same manner making the society entrepreneurial. Unlike the tradition of focusing the development to the adults especially the retirees in order to make a living does not mean making the society entrepreneurial.. Therefore, economic prosperity if it is to be achieved lies in the development of the youth [2].

Many researchers identify the determinants of entrepreneur intentions by analyzing different sets of variables. Such as the research conducted by (Florea, 2019) conclude that locus of control, need for achievement and entrepreneurial education influenced students' choice in being involved in entrepreneurial activities. The other Author findings indicate that a strategy that focuses on building social capital is more likely to result in the formation of the entrepreneurial attitude. Education and training that focuses on interpersonal relationships more than personal characteristics and traits would appear to offer a more promising pathway to entrepreneurship [3].

Human behavior is guided by different subjective probabilities that means believes about the consequence of behavior believes about the normative expectations of other people and believes the presences of factors which may facilitate or impend performance of the behavior. Believes are based on wide range of background factors in their behavioral believes produce attitude towards behavior, normative believes result in subjective norm and control believes generate perceived behavior control. There for theory of paned behavior (TPB) identify five factors that affect personal intentions which are personal background behavior, attitude towards behavior, subjective norm, perceived behavior control and intentions [4].

the basic problems of the study is in our country Ethiopia, the number of lobour force increase but under developed employment opportunity. Youth employment opportunity is inadequate due to the day today increase mental problems of youth unemployment, in adduct entrepreneurship information gaps lacks of knowledge and skills of entrepreneurs. The inadequate youth employment leads many problems such as socio-economic, political and moral consequences. On the other hand entrepreneurs spastically graduate youth entrepreneurs are the most power full economics force of ounce's country growth by participating in creativity and innovation, enterprise creation, and commercialization.

The main objectives of this study was identifying the major determinant factors of entrepreneur intention of university graduate student by reviewing 20 papers which were conducted in this area study from the year 2013 up to 2019. based on the Ajzen theory of paned behavior (TPB), the researcher identify which factors are significantly affects and how the determinant variables affects entrepreneurship intentions of university graduate students with respect to among the research funding of each paper.

There for researcher motivated to assessing the determinant of entrepreneur intentions of university graduate students in Ethiopia through critical review of papers to identifying the main problems and the most significant factors among different factors of entrepreneur intention in the area, finally finding the best solution for the existing problems to recommend the individual entrepreneur to strength and develop their entrepreneurship skills and knowledge as well as the government body's to establish suitable polices in the area to initiate and motivate graduate entrepreneurs.

\section{ConceptualFramework}

Based on the (Ajzen, 1991) theory of planed behavior the researcher develops a conceptual framework. In this study, the dependent variable is entrepreneurial intentions of graduate students and the independent variables are personal background, attitude, perceived behavior and Subjective norm.

The constructs and relationships between the research variables are illustrated in the following figure.

\section{Independent Variables Dependent Variables}

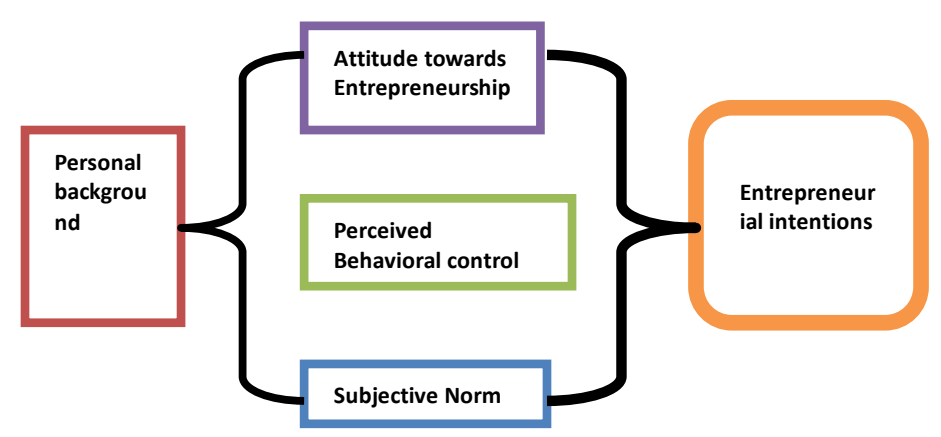

Figure 1. Conceptual Frame work Source: researcher developed based on (Ajzen, 1991)

\section{Research Methodology}

The objective of this research was to analysis determinants of entrepreneurship intentions of university graduating students through review of empirical literature. The study was conducted on the selected published papers between the years 2013 up to 2019 G.C. Which carried out in the same topic area? The rational for selecting this area was different studies identifies various factors that affect entrepreneurship intentions. So this research highly 
motivated to evaluate each author work to drown common and most significant determinant factors that affect entrepreneurship intentions of graduate student. primary data from university graduate student due to the pandemic corona virus (COVID -19).

Easily available published papers were collected for the aim of the review. Exploratory research design was implemented to analysis the cross link effects of variables. Both qualitative and quantitative research approach was used to summarize and quantify the researchers finding. secondary types of data was used to as source of data which collected from 16 number of papers that conducted in the same topic area between the year 2013 and 2019 G.C through critical review method of data collection. The collected data from the reviewed papers were presented and analyzed. The study was employed both Descriptive and inferential statics method of data analysis. Descriptive statistical method was implemented to analysis the selected paper data by using tables, frequency and percentage to summarize the result. Inferential statistics used to measure the relationship between dependant and independent variables. Multiple leaner regression was implemented to identified the most significant factors which affect entrepreneur intentions among the variables which identified by each author and correlation coefficient used to identify what types of relationship occurred between each variables.
The second reason why the researcher interested to do these types of research was the difficulty of collecting

After the data reviewed from 16 papers, conclusions were drown based on the evidence resulted from the papers with the comparison of Ajzen planed theory of behavior (PTB) and the researcher identifying the most significant factors that affect entrepreneurship intentions of university graduate student which studied in the past 2013 up to 2019 year Finally scientific predictions and recommendations were made to the concord body as well as future research.

\section{Data presentation and analysis}

In this section the overall the research variables (dependant and independent variable) and researchers finding and result were presented, analyzed an summarized.

\subsection{Descriptive Statistics of research variable}

the research conducted on detriments of entrepreneurial intentions of university graduate student, published in the year between 2013 up to 2019 a total paper of 16 was identifies different number of determinate variables. The overall determinant variable identified by 16 author Papers which are the dependant independent variables the case area and year of publications were presented in the following table.

Table 4.1.The research variable

\begin{tabular}{|c|c|c|c|c|}
\hline No. & Independent variables s/ Factor & Dependant variable & $\begin{array}{l}\text { Year } \\
\text { /publication }\end{array}$ & $\begin{array}{l}\text { Case area/ } \\
\text { university }\end{array}$ \\
\hline 1. & $\begin{array}{l}\text { - Family Background } \\
\text { - educational Factors } \\
\text { - Personal Factors }\end{array}$ & Entrepreneurial Attitude & 2019 & $\begin{array}{l}\text { Addis } \\
\text { Abeba }\end{array}$ \\
\hline 2. & $\begin{array}{l}\text { - Personality attitude } \\
\text { - Subjective norm } \\
\text { - Personality behavior }\end{array}$ & Entrepreneurial intention & 2018 & $\begin{array}{l}\text { Addis } \\
\text { Abeba }\end{array}$ \\
\hline 3. & $\begin{array}{l}\text { - Background factor } \\
\text { - Perceived social norm } \\
\text { - Perceived behavioral control }\end{array}$ & Entrepreneurial intention & 2014 & $\begin{array}{l}\text { Addis } \\
\text { Abeba }\end{array}$ \\
\hline 4. & $\begin{array}{l}\text { - Willingness } \\
\text { - students' desire } \\
\text {-Entrepreneurship course }\end{array}$ & Desire to be An Entrepreneur & 2017 & Adama \\
\hline 5. & $\begin{array}{l}\text { - Entrepreneurial attitude } \\
\text { - Entrepreneurial education } \\
\text { - Demographic factors } \\
\text { - Socio-economic factor }\end{array}$ & Self-Employment Intention & 2018 & Bahirdar \\
\hline 6. & $\begin{array}{l}\text { - Attitude towards entrepreneurship } \\
\text { - perceived social norms } \\
\text { - perceived behavioral control }\end{array}$ & Entrepreneurial intention & 2018 & Bahirdar \\
\hline 7. & $\begin{array}{l}\text { - Attitude towards entrepreneurship } \\
\text { - perceived social norms } \\
\text { - perceived behavioral control } \\
\text { - Entrepreneurial education } \\
\text { - external environment }\end{array}$ & Entrepreneurial intention & 2019 & $\begin{array}{l}\text { Debre } \\
\text { Berhan }\end{array}$ \\
\hline
\end{tabular}




\begin{tabular}{|c|c|c|c|c|}
\hline 8. & $\begin{array}{l}\text { - Attitude towards entrepreneurship } \\
\text { - Proactive Personality } \\
\text { - Participation in entrepreneurship } \\
\text { education } \\
\text { - Entrepreneurial environment } \\
\text { - Perceived behavioral control } \\
\text { - Subjective norm }\end{array}$ & Self-Employment Intention & 2016 & Dire Dawa \\
\hline 9. & $\begin{array}{l}\text { - Attitude towards entrepreneurship } \\
\text { - proactive behavior } \\
\text { - risk taking behavior } \\
\text { - social norms } \\
\text { - participation in entrepreneurial education } \\
\text { - self employed parents } \\
\text { - perceived behavioral control } \\
\text { - attitude towards university education } \\
\end{array}$ & $\begin{array}{l}\text { Entrepreneurial Intentions and } \\
\text { Behaviors }\end{array}$ & 2017 & Hawassa \\
\hline 10. & $\begin{array}{l}\text { - family business background } \\
\text { - perceived desirability of entrepreneurial value } \\
\text { - perceived self efficiency of entrepreneurial } \\
\text { venture }\end{array}$ & Entrepreneurial Intentions & 2013 & Hawassa \\
\hline 11. & $\begin{array}{l}\text { - demographic variables, } \\
\text { - entrepreneurial career aspiration } \\
\text { - entrepreneurial perceived constraint }\end{array}$ & Entrepreneurial Intentions & 2018 & Jimma \\
\hline 12. & $\begin{array}{l}\text { - Desire and certainty } \\
\text { - willingness to assume risk } \\
\text { - access to credit } \\
\text { - government policy } \\
\text { - family and friend support } \\
\text { - convenience environment } \\
\text { - Residential status (Urban, Rural) } \\
\end{array}$ & $\begin{array}{l}\text { Entrepreneurial Attitude of } \\
\text { Prospective }\end{array}$ & 2017 & Jimma \\
\hline 13. & $\begin{array}{l}\text { - personality-traits factors, } \\
\text { - Attitude toward the entrepreneurship } \\
\text { education, } \\
\text { - Risk taking, } \\
\text { - attitude towards behavior } \\
\text { - subjective norms } \\
\text { - perceived behavioral control } \\
\text { - perceived desirability of self-employment } \\
\text { - Perceived support }\end{array}$ & Entrepreneurial Intentions & 2017 & $\begin{array}{l}\text { Oromiya } \\
\text { Regional } \\
\text { State }\end{array}$ \\
\hline 14. & $\begin{array}{l}\text { - Entrepreneurial education } \\
\text { - social norm, } \\
\text { - entrepreneurial attitude } \\
\text { - self-efficacy } \\
\text { - entrepreneurial motivation } \\
\text { - perceived behavioral control } \\
\end{array}$ & Sustainable Entrepreneurship & 2019 & Wolkite \\
\hline 15. & $\begin{array}{l}\text { - education profession attraction } \\
\text { - locus of control } \\
\text { - motivation for achievement }\end{array}$ & Entrepreneurial Intentions & 2016 & $\begin{array}{l}\text { Wolaita } \\
\text { Sodo }\end{array}$ \\
\hline 16. & $\begin{array}{l}\text { - Attitude } \\
\text { - perceived behavioral control } \\
\text { - subjective norm, } \\
\text { - demographic characteristics } \\
\text { - Entrepreneurship education }\end{array}$ & Entrepreneurial Intentions & & Wollega \\
\hline
\end{tabular}


According to the above table various factors which affect entrepreneurial intentions among university student. from 17 a total number of research papers the most research variable are the same and including the theory of planed behavior where as small number of research papers took other variable different from

Table 4.2. Summery of determinant variable
Ajzen theory of planed behavior as determinant variable. The following table shows that a summary of determinant variables without repetition atonal of 10 variables as well as the frequency and percentage of each variable from the total of 17 papers that affect entrepreneurial intention.

that Bahir Dar university business student have

\begin{tabular}{llll}
\hline No. & Determinant variable & Frequency & Percentage from100 \% \\
\hline 1. & attitude towards entrepreneurship & 12 & 18.46 \\
2. & Perceived Social Norms & 8 & 12.31 \\
3. & Perceived Behavioral Control & 7 & 10.77 \\
4. & Entrepreneurship Education, & 9 & 13.85 \\
5. & External Environment & 6 & 9.23 \\
6. & Demographic characteristics & 2 & 3.07 \\
7. & Risk taking, & 3 & 4.62 \\
7. & Locus of Control & 3 & 4.62 \\
8. & Motivation for Achievement & 6 & 9.23 \\
9. & Personal Background factor & 9 & 13.85 \\
\hline
\end{tabular}

The table illustrates that majority number of research papers $18.46 \%$ (12) are identified attitude towards entrepreneurship recognized as the fist a determinant factors followed by Entrepreneurship Education 13.85 (9), Personal Background factor13.85(9) and Perceived Social Norms 12.31 (8) are the second and third levels respectively.

Perceived Behavioral control10.77 (7), Motivation for achievement 9.3 (6) and external environments 9.23 (6) are the medium determinant variables selected by the researchers as a determinant variables whereas Risk taking 4.63 (3), Locus of Control 4.63 (3), and demographic characteristic 3.07 (2) had least position in the researchers selection as a determinant variables.

From this it is possible conclude that the determinant variables terms of researchers variable selection most researchers include attitude towards entrepreneurship, entrepreneurship education personal background factor and perceived social norms and a medium number of researchers incorporate Perceived Behavioral control Motivation for achievement and external environments as determinant variable. On the other hand Risk taking, Locus of Control and demographic characteristic variables are put on the least preferable variable to be a determinant variable on entrepreneurial intention of university graduate student in Ethiopia.

\subsection{Summary of researchers finding}

According to [5] Entrepreneurial intentions of the student is strong relation with personal attitude and perceived behavior control affects entrepreneurial intentions strongly and positively in fact statically significant [6]. Research conducted by [7] indicates positive attitudes, subjective, high self efficiency intentions to self employment self-employment. The other author study finding shows that the main effect, namely attitude towards entrepreneurship, perceived subjective norm and perceived behavioral control have positive relationship and significant effect on entrepreneurial imitations among graduate student. it is also found that entrepreneurship education has positive moderating effect on entrepreneurial insertion among graduate student[8]. Entrepreneurial intention of the respondents affected by personalitytraits factors, Attitude toward the entrepreneurship education, Risk taking, attitude towards behavior, subjective norm, perceived behavioral control, perceived desirability of self-employment and Perceived support factors and the finding reveal that theory of planed behavior (TPB) is a valuable tool in understanding entrepreneurial intentions of graduate student[9].

A research by [10] suggests that motivation to pursue entrepreneurship is consistence with the theory of planed behavior. However, there are unique social cultural factors, which require considerations for addressing the current obstacles facing entrepreneurial growth. According [11] finding social norm and entrepreneurial motivation had a positive and significant influence on potential university graduates intention towards sustainable entrepreneurship. Proactive personality Participation in entrepreneurship perceived behavioral control attitude toward university entrepreneurial environment was also significant factors for students entrepreneurial / self employment intentions However subjective norms wasn't statically significant in determining DDU students entrepreneurial intentions [12]. Professional attraction, locus of control and motivation for achievement were 
identified as significant dimensions of entrepreneurship among the studied population [13].

The result obtained prove that the cours entrepreneurship givent to graduate of higher eduction incrase their entreprenrial desire and entrepreneurial education positively influences students perceptions of self employment and hence self employment intentions [14]. The research by [15] resuat shows that the combined indirect effect of personality and attitude towards entrepreneurial intentions are almost as high as the direct effect of perceptions in entrepreneurial education on these intention. there is significant association between entrepreneurial intention, entrepreneurial motivations and parent own business[16]. Other author [17] study found that entrepreneurial attitude do have significance impact on students self employment intention. it shows that entrepreneurial education/ traning and entrepreneurial attitude significantly predicts students self employment intentions .

A research by [18] result shows that there is positive relationship between dimensions of entrepreneurship and intention towards entrepreneurship among university student. Moreover the two dimensions of entrepreneurship, family business background and perceived self efficacy explain the variation on students intention to start a new venture. Based on the finding of this study concluded that the existence of high entrepreneurial intentions among final year graduate agriculture student in Ethiopia is certain and has strong desire to establish their own business [19].

\section{Conclusion}

On top of the review of 17 number of papers the research concludes that attitude towards entrepreneurship has a significant positive influence entrepreneurial intentions of graduate student. In addition the study concludes that attitude toward the behavior, Subjective norms and perceived behavior control have a significant positive influence on entrepreneurial intentions of graduate student in Ethiopia. and also this research concluded that entrepreneurship education External Environment personal background factor, locus of control, motivation for achievement and demographic characteristics have moderate significant positive influence on entrepreneurial intentions of graduate student in Ethiopia. finally the study conclude that it is true that the Ajzen theory of planed behavior (attitude towards behavior, the Behavior, subjective norm and perceived behavior control ) are a basic tools to identify entrepreneurial intentions of graduate student as a determinant variables.

\section{References}

[1]. Huub L.M. Mudde, D. T. (July 2015). Entrepreneurship Education In Ethiopian Universities Institutional Assessment . Education Strategy Center . Maastricht School Of Management Msm.

[2]. Dioneo-Adetayo, E. A. (2006). Factors Influencing Attitude Of Youth Towards Entreprenuership. International Journal Of Adolescence And Youth , 13 (1-2).

[3]. Radha Jagannathan, M. J. (2017). Family, Society And The Individual: Determinants Of Entrepreneurial Attitudes Among Youth In Chennai, South India. 7 (14).

[4]. Ajzen. (1991). Theory Of Planed Behavior (Vol. 50).

[5]. Andualem, W. (2019). Entrepreneurial Attitude Of Addis Ababa University Graduatingstudents - The Case Of School Of Commerce. Ictact Journal On Management Studies, , 05 ( 01).

[6]. Alemseged G, M. (2018). Examining Entrepreneurial Intentions An Its Correlates Among Undergraduat Studnt In Ethiopia Emperical Study. Journal Of Higher Education Theory And Practice, 18 (3).

[7]. Waliezewdu, M. A. (2018). Determinants Of Entrepreneurial Intention Of Graduating Students At Bahirdar University: An Application Of Theoryof Planned Behavior. Arabian Journal Of Business And Management Review (Oman Chapter), 7 (1).

[8]. Melaku, D. F. (2019). Factors Affecting Entrepreneurial Intention Among Graduating Students At Debre Berhan University, Ethiopia. Journal of Investment And Management. , 8 (1).

[9]. Sileshi Leta, W. (2017). Determinants Of Entrepreneurial Intention Of University Graduates In Oromia Regionalstate, Ethiopia. International Journal Of Research In Social Sciences , 7 (5).

[10]. Alkdahim, Z. (2014, December 2). Entrepreneurial Intention Of Graduating Students:Determinants, Challenges, And Policy Implications. Case Studyaddis Ababa University.

[11]. Habtamu, G. (2019). Factors For Potential Entrepreneurs Intention Towards Sustainable Entrepreneurship: The Case Of Wolkite Universitygraduate Students' In Ethiopia. Global Scientific Journal , 7 (12).

[12]. Aschalew, M. (2016). Analysis On Determinants Of Students Self Employment Intention In Newly Established Universities Of 
Ethiopia. International Journal Of Scientific And Research Publications , 6 (4).

[13]. Yonatan, D. T. (2016). Determinants Of Entrepreneurial Intention Among Prospective Graduates Of Higher Institutions Case Of Wolaita Sodo University. Journal Of Education And Practice, 7 (16).

[14]. Messele, K. (2017). Assessment Of Higher Education Students' Desire To Be An Entrepreneur: The Case Study Of Adama Science Andtechnology University. Global Journal Of Management And Business Research: Administration And Management , 17 (4).

[15]. Demeke, A. (2017). Entrepreneurial Intentions And Behaviors Among Hawassa University Graduating Students, Ethiopia. European Journal Of Business And Management , 9 (31).

[16]. Biru Desta, T. J. (2018). Factors Affecting Entrepreneurial Attitude Of Prospective Graduates In Jimma University. 8 (3).

[17]. Mesfin Mulu, A. A. (2018). Modeling The Impact Of Entrepreneurial Attitude On SelfEmployment Intention Among Engineering Students In Ethiopia. Journal Of Innovation And Entrepreneurship , 7 ( 8).

[18]. Mesay, S. (2013). Entrepreneurial Intention Among Undergraduate Business Students. International Journal Of Research In Management, Economics And Commerce , 3 (9).

[19]. Sultan, J. (2017). Entrepreneurial Intention Among Undergraduateagricultural Students In Ethiopia: The Case Of Jimma University. African Journal Of Business Management , 11 (13). 